\title{
Anaerobiospirillum species isolated from humans with diarrhoea
}

\author{
H MALNICK, MEM THOMAS, ${ }^{*}$ H LOTAY, ${ }^{*}$ M ROBBINS \\ From the National Collection of Type Cultures and Epidemiological Research Laboratory, Central Public \\ Health Laboratory, London NW9 5HT, and the *Department of Clinical Microbiology, University College \\ Hospital, London WC1E $6 A U$
}

SUMMARY Flagellated anaerobic motile spiral bacteria were isolated from the faeces of two patients with diarrhoea. They were recovered by the microaerophilic culture method used to detect campylobacters but demanded anaerobic conditions for subculture. Electron microscopy and other investigations showed them to be closely related to Anaerobiospirillum succiniproducens first described in beagle dogs and subsequently in three humans with bacteraemia.

Anaerobic spiral bacteria in the human bowel have not often been reported. When found, such organisms have been of two types, spirochaetes with axial fibrils ${ }^{1-7}$ and non-spirochaetes without visible axial fibrils. ${ }^{38}$ We here report the isolation of relatively anaerobic flagellated spiral bacteria from the faeces of two patients with diarrhoea.

\section{Material and methods}

The organisms were isolated during the routine diagnostic examination of faecal specimens. The first patient (A30) was a 41-year-old man who had recurrent pain and loose stools, the second (A142) was a child who attended a local Day Nursery. Rotavirus, Shigella, Salmonella and Campylobacter species were not found in either patient. Faeces from 34 child contacts of A142 were examined, but the spiral organism was found in this one case only. Six other children were excreting Shigella sonnei.

The two spiral organisms were designated A30 and $\mathrm{A} 142$ respectively.

\section{CULTURE METHODS}

The methods in routine use for the recognition of intestinal pathogens included a selective medium for campylobacters containing vancomycin, polymyxin and trimethoprim ${ }^{9}$ which was incubated for $48 \mathrm{~h}$ at $43^{\circ} \mathrm{C}$ employing a BBL Campylobacter ("Campypak") sachet in a jar to secure a microaerophilic atmosphere.

Both strains of spiral bacterium were initially isolated by this method, but anaerobic incubation Accepted for publication 25 May 1983 was required for regular successful subculture. Oxygen and temperature tolerance were investigated in parallel on $5 \%$ horse blood agar, chocolate agar, lysed blood agar and buffered charcoal yeast extract agar (BCY) ${ }^{10}$ using an evacuation system in an anaerobic jar, incubated at a range of temperatures between $30^{\circ} \mathrm{C}$ and $45^{\circ} \mathrm{C}$. Ninety per cent hydrogen and $10 \%$ carbon dioxide gas were utilised as a basic atmosphere to obtain a comparison between oxygen concentrations of $5 \%, 4 \%$ and $3.5 \%$ and strict anaerobiosis.

\section{FERMENTATION AND BIOCHEMICAL TESTS}

Cell suspensions in distilled water were made from 24-hour anaerobic cultures on blood agar and used for inoculation. The methods of Cowan and Steel ${ }^{11}$ were used with the following modifications; skimmed milk powder was used for testing casein hydrolysis; sodium nitrate for nitrate reduction and $0.4 \%$ starch for starch hydrolysis. The blue catalase test, ${ }^{12}$ which traps bubbles, was compared with the standard method. The basal medium for testing acid production from carbohydrates and glucose fermentation products was peptone yeast broth. ${ }^{13}$ The end products of glucose fermentation were analysed by gas liquid chromatography on a Pye Unicam Series 204 Chromatograph.

\section{ANTIBIOTIC SENSITIVITY}

The disc method was used on blood agar and BCY incubated anaerobically at $37^{\circ} \mathrm{C}$ and $43^{\circ} \mathrm{C}$. A strain of Campylobacter jejuni freshly isolated from a blood culture was tested in parallel on media incubated microaerophilically. 


\section{CELL MORPHOLOGY}

Gram-stained impression preparations were examined after 24 and $48 \mathrm{~h}$ culture on $5 \%$ horse blood agar and BCY in microaerophilic and anaerobic atmospheres at $37^{\circ} \mathrm{C}$ and at $43^{\circ} \mathrm{C}$. For electron microscopy (EM), cultures on BCY medium incubated anaerobically at $37^{\circ} \mathrm{C}$ for 24 and $48 \mathrm{~h}$ were scraped and suspended in $2 \%$ formaldehyde solution. The bacterial cells were stained with $1 \%$ phosphotungstic acid and then examined under an AEI EM6B electron microscope. The wavelength and amplitude of the spirals seen were measured on EM photographs and compared with those recorded for typical Anaerobiospirillum succiniproducens $^{14}$ and Campylobacter jejuni ${ }^{15}$ strains (Table 1).

\section{Results}

\section{MORPHOLOGY}

The initial cultures A30 and A142 were obtained on campylobacter selective medium incubated microaerophilically at $43^{\circ} \mathrm{C}$ for $48 \mathrm{~h}$. They resembled Campylobacter jejuni in colonial and microscopic appearance but were oxidase-negative and were difficult and often impossible to subculture microaerophilically. However they grew well after $24 \mathrm{~h}$ in an anaerobic atmosphere on 5\% horse blood agar, chocolate agar, lysed blood agar and BCY medium, but not on nutrient agar. The temperature tolerance extended from $32^{\circ} \mathrm{C}$ to $43^{\circ} \mathrm{C}$. Colonies on blood agar after 24 hours at $37^{\circ} \mathrm{C}$ were 0.5 to $1 \mathrm{~mm}$ in diameter, translucent and non-haemolytic, with some delicate spreading or swarming peripheral growth which was more marked at $43^{\circ} \mathrm{C}$ than at $37^{\circ} \mathrm{C}$ (Fig. 1). Impression films showed Gramnegative spiral organisms 3-5 $\mu \mathrm{m}$ long and $0.5 \mu \mathrm{m}$ wide (Fig. 2), after 24 hours incubation but at 48 hours the cells had elongated up to $34 \mu \mathrm{m}$ with as many as 20 regularly spaced spirals (Fig. 3 ). Older cultures became progressively more fragmented and coccoid. Dark field microscopy revealed spiral motile cells which revolved around their long axes. Electron microscopy showed these cells to have bipolar tufts of multiple flagellae (Figs. 4 and 5). Organism A30 had a spiral wavelength of $1.4-2 \mu \mathrm{m}$ with an amplitude of $0 \cdot 23-0.35 \mu \mathrm{m}$, while A142 had a wavelength of $1 \cdot 7-2.2 \mu \mathrm{m}$ and an amplitude of 0.2-0.65 $\mu \mathrm{m}$ (Table 1).

Table 1 Characteristics of spiral organisms A30 and A142 compared with those of Anaerobiospirillum succiniproducens ${ }^{14}$ and Campylobacter jejuni ${ }^{15}$

\begin{tabular}{|c|c|c|c|c|}
\hline & A30 & $A 142$ & A succiniproducens & C jejuni \\
\hline \multicolumn{5}{|l|}{ Acid from: } \\
\hline Fructose & + & - & + & - \\
\hline Glucose & + & + & + & - \\
\hline Inositol & - & - & - & - \\
\hline Lactose & - & - & + & - \\
\hline Maltose & - & - & $\mathbf{v}$ & - \\
\hline Mannitol & - & - & - & - \\
\hline Rafifinose & - & - & + & - \\
\hline Salicin & - & - & - & - \\
\hline Sorbitol & - & - & - & - \\
\hline Sucrose & - & - & + & - \\
\hline Trehalose & + & - & $\mathbf{v}$ & - \\
\hline Casein & - & - & NT & - \\
\hline Oxidase & - & - & - & + \\
\hline Catalase & - & - & - & + \\
\hline Blue catalase test & trace & trace & trace & + \\
\hline \multicolumn{5}{|l|}{$\begin{array}{l}\text { Glucose fermentation: } \\
\text { acetic \& succinic acid }\end{array}$} \\
\hline as major end products & + & + & + & - \\
\hline \multicolumn{5}{|l|}{ Subculture growth: } \\
\hline anaerobic & + & + & + & - \\
\hline aerobic & - & - & - & - \\
\hline $3.5-5 \% \mathrm{O}_{2}$ & - & - & - & + \\
\hline Lecithinase $^{2}$ & - & - & $\mathbf{v}$ & - \\
\hline Methyl red & - & - & NT & - \\
\hline Nitrate reduction & - & - & - & + \\
\hline ONPG & - & - & NT & - \\
\hline Phosphatase & - & - & NT & NT \\
\hline Starch hydrolysis & - & - & $\mathbf{v}$ & - \\
\hline \multicolumn{5}{|l|}{ Temperature: } \\
\hline $\begin{array}{l}\text { Maximum } \\
\text { Minimum }\end{array}$ & $\begin{array}{l}43^{\circ} \mathrm{C} \\
32^{\circ} \mathrm{C}\end{array}$ & $\begin{array}{l}43^{\circ} \mathrm{C} \\
32^{\circ} \mathrm{C}\end{array}$ & $\begin{array}{l}40^{\circ} \mathrm{C} \text { approx } \\
25^{\circ} \mathrm{C} \text { approx }\end{array}$ & $\begin{array}{l}43^{\circ} \mathrm{C} \\
37^{\circ} \mathrm{C} \text { approx }\end{array}$ \\
\hline Urea hydrolysis & -32 & - & 25 approx & \\
\hline $\begin{array}{l}\text { Spiral wavelength }(\mu \mathrm{m}) \\
\text { Amplitude }(\mu \mathrm{m})\end{array}$ & $\begin{array}{l}1.4-2 \\
0.23-0.35\end{array}$ & $\begin{array}{l}1 \cdot 7-2.2 \\
0.2-0.65\end{array}$ & $\begin{array}{l}1 \cdot 3-1 \cdot 7 \\
0 \cdot 9-1 \cdot 1\end{array}$ & $\begin{array}{l}0.9-1.3 \\
0.35-0.6\end{array}$ \\
\hline
\end{tabular}

$\mathrm{v}=$ variable, $\mathrm{NT}=$ not tested. 


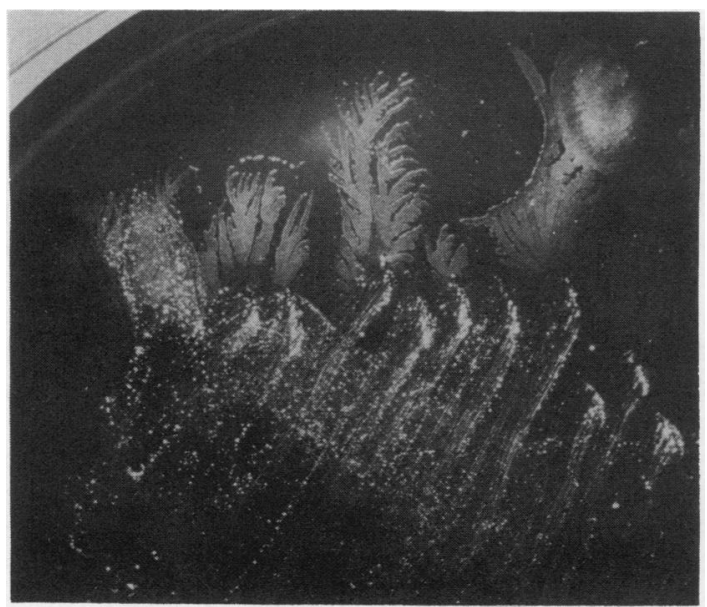

Fig. 1 Feathery swarming growth of Anaerobiospirillum on surface of blood agar after 48 hours anaerobic incubation $\times 2$.

\section{BIOCHEMICAL AND FERMENTATION TESTS}

The results are summarised in Table 1 which includes a comparison with some reactions characteristic of type strains of Anaerobiospirillum succiniproducens and of Campylobacter jejuni. Oxidase tests were negative. Conventional catalase tests were also negative, but a trace reaction was obtained consistently with the more sensitive blue peroxide

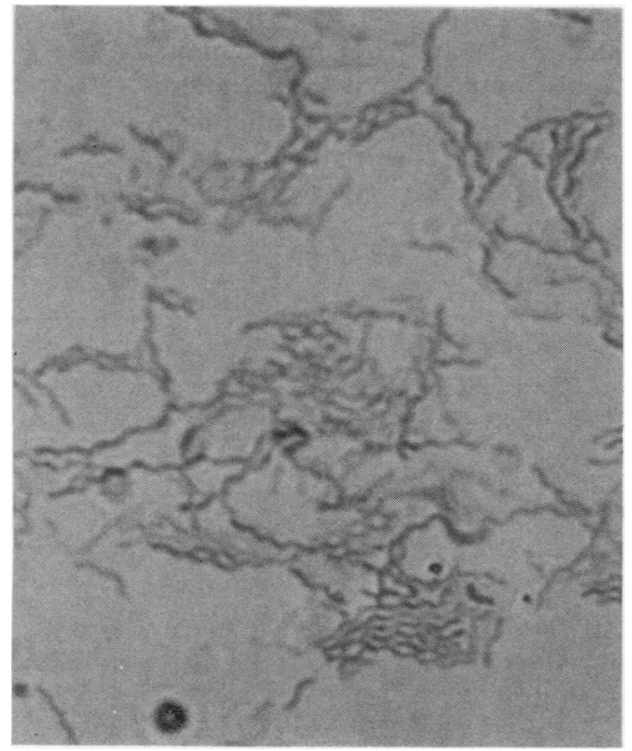

Fig. 2 Impression film of Anaerobiospirillum cultured anaerobically on blood agar for 48 hours, stained Gram $\times 1600$.

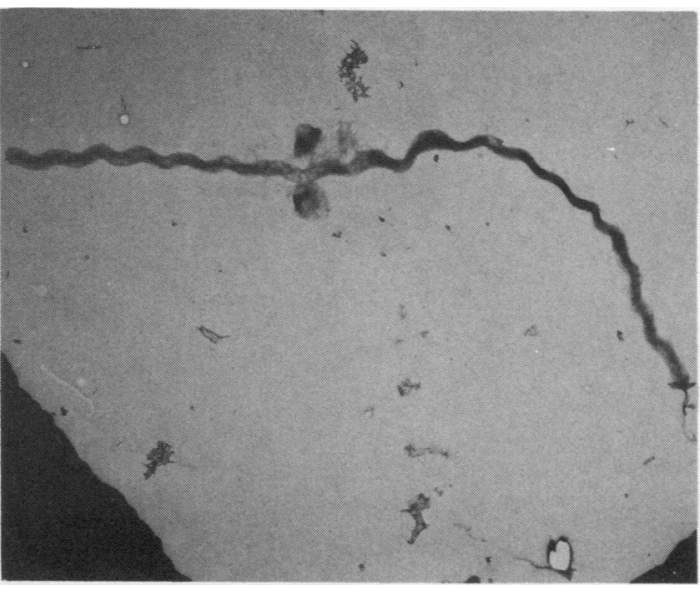

Fig. 3 Electron micrograph of Anaerobiospirillum cultured on $B C Y$ for 48 hours, showing many spirals $\times 2250$.

catalase test ${ }^{12}$ with which the type strain of $A$ succiniproducens also gave a trace reaction. Gas liquid chromatography detected acetic and succinic acids as major end products of glucose fermentation by both $\mathrm{A} 30$ and $\mathrm{A} 142$, as by the type species $A$ succiniproducens; but not by $C$ jejuni.

The two spiral organisms A30 and A142 resembled each other and $A$ succiniproducens in cultural requirements and morphology but differed slightly in biochemical tests. They differed culturally, morphologically and biochemically from campylobacters.

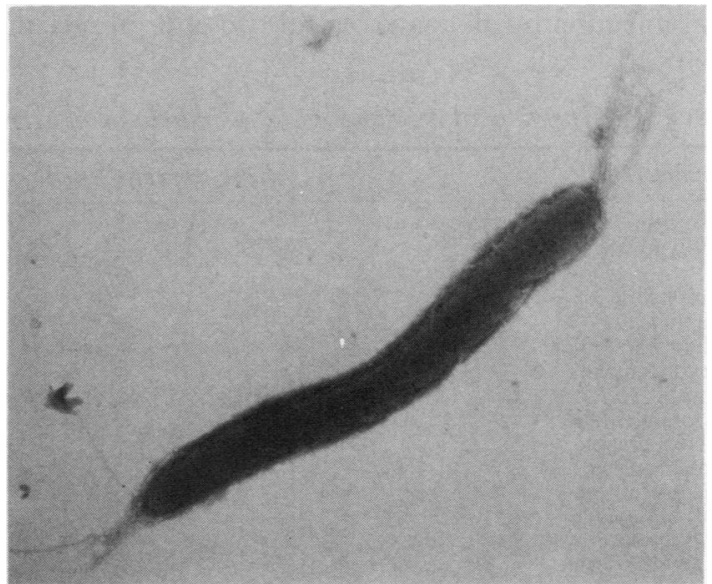

Fig. 4 Electron micrograph of Anaerobiospirillum cultured on BCY for 24 hours, showing bipolar tufts of flagella $\times 13500$. 


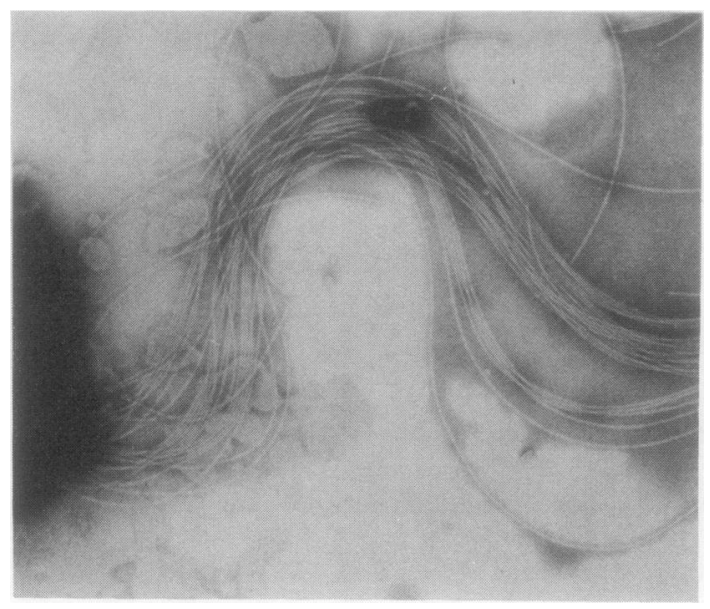

Fig. 5 Electron micrograph of Anaerobiospirillum cultured on $B C Y$, showing flagella tuft at higher magnification $\times 29250$.

\section{ANTIMICROBIAL SENSITIVITY}

The results of disc sensitivity tests are shown in Table 2. They were the same on BCY and blood agar plates at $37^{\circ} \mathrm{C}$ and $43^{\circ} \mathrm{C}$. Apart from a difference in the degree of resistance to gentamicin, A30 and A142 were alike. They were, unlike $C$ jejuni, more sensitive to penicillin than to erythromycin. Although sensitive to the standard 300 unit polymyxin disc they grew on a campylobacter selective medium ${ }^{9}$ which contained polymyxin $2 \cdot 5$ units per $\mathrm{ml}$.

\section{Discussion}

There have not been many reports of human intestinal infection by elongated spiral bacteria. In recent descriptions the diagnosis has been achieved by histological examination of biopsy material and by electron microscopy. ${ }^{1-816}$ Most of these reports describe bacteria with axial filaments, confirming that they belong to the Family Spirochaetaceae. Takeuchi et $a l^{317}$ however, observed an organism with single bipolar flagella in colonic epithelium from humans and from rhesus monkeys, but did not indicate whether it had been cultured. Two reports concern long spiral bacteria which were successfully cultured; one of these showed neither axial fibrils nor flagella ${ }^{8}$ and the other was not examined by electron microscopy..$^{18}$ In 1976 Davis et al ${ }^{14}$ reported the isolation of an Anaerobiospirillum species from the mouth and faeces of beagle dogs and proposed the type species $A$ succiniproducens. This organism has since been recovered from blood cultures in three febrile adult human patients. ${ }^{1920}$ Like $A$ succiniproducens, the two anaerobic spiral organisms we describe have bipolar tufts of flagella, but they differ slightly from the type strain and from each other in their pattern of carbohydrate fermentation. On the basis of tests carried out so far we conclude that A30 and A142 are Anaerobiospirillum species, but not necessarily $A$ succiniproducens. Although they were isolated from the faeces of patients suffering from diarrhoea there is insufficient evidence on which to ascribe pathogenicity. It may however prove worthwhile to seek such bacteria in future. Although essentially anaerobic and intolerant of oxygen on subculture, both A30 and A142 were initially isolated microaerophilically on a campylobacter selective medium incubated at $43^{\circ} \mathrm{C}$ for $48 \mathrm{~h}$ and the strains were moderately sensitive to metronidazole. At that stage the colonial form and the appearance of Gram-stained bacteria closely resembled those of a campylobacter although some

Table 2 Sensitivity of $A 30$ and A142 to antimicrobial agents

\begin{tabular}{|c|c|c|c|c|}
\hline Antimicrobial & Disc content $(I U / \mu g)$ & $A 30$ & $A 142$ & Campylobacter jejuni $\dagger$ \\
\hline $\begin{array}{l}\text { Penicillin } \\
{ }^{*} \text { Polymyxin }\end{array}$ & $\begin{array}{r}2 \text { IU } \\
300 \text { IU }\end{array}$ & $\begin{array}{l}\mathbf{S} \\
\mathbf{S}\end{array}$ & $\begin{array}{l}\mathbf{S} \\
\mathbf{S}\end{array}$ & $\begin{array}{l}\mathbf{R} \\
\mathbf{R}\end{array}$ \\
\hline $\begin{array}{l}\text { Ampicillin } \\
\text { Cephalexin } \\
\text { Chloramphenicol } \\
\text { Erythromycin } \\
\text { Fusidic acid } \\
\text { Gentamicin } \\
\text { Metronidazole } \\
\text { Nalidixic acid } \\
\text { Nitrofurantoin } \\
\text { Sulphafurazole } \\
\text { Tetracycline } \\
\text { *Trimethoprim } \\
\text { *Vancomycin }\end{array}$ & $\begin{array}{l}10 \\
30 \\
10 \\
10 \\
10 \\
10 \\
5 \\
30 \\
50 \\
100 \\
10 \\
1 \cdot 25 \\
35\end{array}$ & $\begin{array}{l}\mathbf{S} \\
\mathbf{S} \\
\mathbf{S} \\
\mathbf{M} \\
\mathbf{R} \\
\mathbf{S} \\
\mathbf{M} \\
\mathbf{M} \\
\mathbf{S} \\
\mathbf{S} \\
\mathbf{S} \\
\mathbf{R} \\
\mathbf{R}\end{array}$ & $\begin{array}{l}\mathbf{S} \\
\mathbf{S} \\
\mathbf{S} \\
\mathbf{M} \\
\mathbf{R} \\
\mathbf{M} \\
\mathbf{M} \\
\mathbf{M} \\
\mathbf{S} \\
\mathbf{S} \\
\mathbf{S} \\
\mathbf{R} \\
\mathbf{R}\end{array}$ & $\begin{array}{l}\mathbf{S} \\
\mathbf{R} \\
\mathbf{S} \\
\mathbf{S} \\
\mathbf{R} \\
\mathbf{S} \\
\mathbf{R} \\
\mathbf{S} \\
\mathbf{S} \\
\mathbf{S} \\
\mathbf{S} \\
\mathbf{R} \\
\mathbf{R}\end{array}$ \\
\hline
\end{tabular}

$\mathbf{S}=$ sensitive $; \mathbf{M}=$ moderately sensitive $; \mathbf{R}=$ resistant .

*Component of the campylobacter selective medium used for isolation.

tStrain from a blood culture. 
Table 3 Typical characteristics of non-aerobic spiral bacteria ${ }^{2122}$

\begin{tabular}{|c|c|c|c|c|c|c|}
\hline & Flagella & $\begin{array}{l}\text { Growth } \\
25^{\circ} \mathrm{C}\end{array}$ & $35^{\circ} \mathrm{C}$ & $40^{\circ} \mathrm{C}$ & Oxidase & $\begin{array}{l}\text { Catalase } \\
\text { (conventional) }\end{array}$ \\
\hline $\begin{array}{l}\text { Microaerophils } \\
\text { Campylobacter spp } \\
\text { Spirillum volutans } \\
\text { Anaerobes } \\
\text { Anaerobiospirillum spp } \\
\text { Desulfovibrio spp } \\
\text { Wolinella spp } \\
\text { Selenomonas spp } \\
\text { Butyrivibrio spp } \\
\text { Succinivibrio spp } \\
\text { Anaerobic spirochaetes }\end{array}$ & $\begin{array}{l}1 \text { polar } \\
\text { bipolar tuft } \\
\text { bipolar tuft } \\
\text { polar tuft } \\
\text { polar tuft } \\
\text { lateral } \\
1 \text { polar } \\
1 \text { polar } \\
\text { axial only }\end{array}$ & $\begin{array}{l}\mathbf{v} \\
+ \\
\mathbf{v} \\
+ \\
- \\
\mathbf{v} \\
- \\
-\end{array}$ & $\begin{array}{l}+ \\
+ \\
+ \\
+ \\
+ \\
+ \\
+ \\
+ \\
+\end{array}$ & $\begin{array}{l}\mathbf{v} \\
+ \\
+ \\
+ \\
\mathbf{v} \\
+ \\
- \\
\mathbf{v}\end{array}$ & $\begin{array}{l}+ \\
+ \\
- \\
- \\
- \\
- \\
-\end{array}$ & $\begin{array}{l}+ \\
+ \\
- \\
- \\
- \\
- \\
-\end{array}$ \\
\hline
\end{tabular}

$\mathrm{v}=$ variable.

spiral cells were very long.

Campylobacter jejuni isolated from faeces at $43^{\circ} \mathrm{C}$ are characteristically oxidase and catalase positive by conventional methods and most strains are fully sensitive to erythromycin, so the negative results we obtained with these three tests indicated the need for further study. Biochemical tests were not found very helpful until an identification to Family level was achieved. At present, as is seen in Table 3, electron microscopy is the best way to discriminate between the known groups of spiral bacteria.

We are grateful to Dr L R Hill, National Collection of Type Cultures for his advice and thank AA Porter and $C$ Paddon of the PHLS Virus Reference Laboratory for the electron micrographs, J Gibson of the Photographic Department for the microphotographs and F Scott for typing the manuscript.

\section{Requests}

Mr H Malnick, National Collection of Type Cultures, Central Public Health Laboratory, Colindale, London NW9 5HT would be grateful to receive strains or information about similar spiral organisms isolated elsewhere

\section{References}

' Harland WA, Lee FD. Intestinal spirochaetosis. Br Med J 1967; iii:718-9.

${ }^{2}$ Lee FD, Kraszewski A, Gordon J, Howie JGR, McSeveney D, Harland WA. Intestinal spirochaetosis. Gut 1971;12:126-33.

${ }^{3}$ Takeuchi A, Jervis HR, Nakazawa H, Robinson DM. Spiralshaped organisms on the surface colonic epithelium of the monkey and man. Am J Clin Nutr 1974;27:1287-96.

4 Drasar BS, Hudson MJ. Spiral organisms in intestinal disease. In: Reeves DS, Geddes AM, eds. Recent advances in infection. Vol 1. Edinburgh: Churchill-Livingstone, 1979:41-53.

5 Douglas JG, Crucioli V. Spirochaetosis: a remediable cause of diarrhoea and rectal bleeding? $\mathrm{Br}$ Med J 1981:283:1362.

- Crucioli V, Busuttil A. Human intestinal spirochaetosis. Scand J Gastroenterol 1981;16(suppl 70):177-9.

7 Tompkins DS, Waugh MA, Cooke EM. Isolation of intestinal spirochaetes from homosexuals. J Clin Pathol 1981;34:13857.
${ }^{B}$ Kaplan LR, Takeuchi A. Purulent rectal discharge associated with a nontreponemal spirochete. JAMA 1979;241:52-3.

'Skirrow MB. Campylobacter enteritis: a "new disease". Br Med J 1977;ii:9-11.

${ }^{10}$ Feeley JC, Gibson RJ, Gorman GW, Langford NC, Rasheed JK, Mackel DC, Baine WB. Charcoal-yeast extract agar: primary isolation medium for Legionella pneumophila. J Clin Microbiol 1979;10:437-41.

"Cowan ST. Cowan and Steel's manual for the identification of medical bacteria. 2nd ed. Cambridge: Cambridge University Press, 1974

12 Thomas MEM. A blue peroxide slide catalase test. Mon Bull Min Hlth PHLS 1963;22:124-5.

${ }^{13}$ Holdeman LV, Cato EP, Moore WEC. Anaerobe laboratory manual 4th ed. Virginia Polytechnic Institute and State University, 1977.

14 Davis CP, Cleven D, Brown J, Balish E. Anaerobiospirillum, a new genus of spiral-shaped bacteria. Int J Syst Bacteriol 1976;26:498-504.

${ }^{15}$ Karmali MA, Grandis SA de, Allen AK, Fleming PC. Identification, nomenclature, and taxonomy of catalasepositive campylobacters. In: Newell DG, ed. Campylobacter, epidemiology, pathogenesis and biochemistry. MTP Press Ltd, 1982, 35-39 (Proceedings of an International Workshop on Campylobacter Infections at the University of Reading, March 1981).

${ }^{16}$ Shera AG. Specific granular lesions associated with intestinal spirochaetosis. Br J Surg 1962;50:68-77.

17 Takeuchi A, Zeller JA. Ultrastructural identification of spirochetes and flagellated microbes at the brush border of the large intestinal epithelium of the rhesus monkey. Infect Immun 1972;6:1008-18.

18 Lambert T, Goursot G. Diarrhée aigue avec hémocultures et coprocultures positives a Tréponema. Med Mal Infect 1982;12:276-8.

${ }^{19}$ Rifkin GD, Opdyke JE. Anaerobiospirillum succiniproducens septicemia. J Clin Microbiol 1981;13:811-3.

${ }^{20}$ Shlaes DM, Dul MJ, Lerner PI. Anaerobiospirillum bacteremia. Ann Intern Med 1982;97:63-5.

${ }^{21}$ Buchanan RE, Gibbons NE, eds. Bergey's manual of determinative bacteriology 8th ed. Baltimore: Williams and Wilkins, 1974.

${ }^{22}$ Tanner ACR, Badger S, Lai CH, Listgarten MA, Visconti RA, Socransky SS. Wolinella gen. nov., Wolinella succinogenes (Vibrio succinogenes Wolin et al.) comb. nov., and descripton of Bacteroides gracilis sp. nov., Wolinella recta sp. nov., Campylobacter concisus sp. nov., and Eikenella corrodens from humans with peridontal disease. Int $J$ Syst Bacteriol 1981;31:432-45.

Requests for reprints to: Dr Mair EM Thomas, Central Public Health Laboratory, Colindale Avenue, London NW9 5HT, England. 